\title{
A Chefia e a Reforma Ministerial
}

\section{Paulo Coriolano Tunis Viana}

Paulo Coriolano Tunis Viana volta a nos oferecer trabalho sôbre a reestruturação do aparelho arrecadador do Ministério da Fazenda, desta vez sob o titulo "A Chefia e a Reforma Ministerial".

Como bom conhecedor do assunto, em suas diversas nuanças, o autor detalha em linhas rápidas trabalho anteriormente empreendido quando de sua permanência na chefia da Seção de Orientação e Inspeção de Coletorias Federais.

O assunto merece exame e consideração, no momento em que se cogita da reforma do Ministério da Fazenda. (NOTA DA REDAÇ̃̃O)

A

REFORMa do Ministério da Fazenda, de cuja realização se acha incumbida a Fundação Getúlio Vargas, e que ora se encontra em fase de plena elaboração, levada a efeito pcr uma comissão composta de destacados técnicos, deve estar intimamente vinculada ao problema da chefia no serviço público federal, sem o que não poderá alcançar seu inteiro objetivo, qual seja o de proporcionar aos órgãos que integrain o sistema fazendário um desejável padrão de dinamismo e eficiência, reclamado pelo preserte momento da vida nacional, em substituição a uma estrutura que de há muito se apresenta irremediàvelrnente gasta e insustentável.

Quando de minha permanência na chefia da Seção de Orientação e Inspeção do Serviço de Coletorias Federais, da Diretoria das Rendas Internas, órgão que tem por função sistematizar̃ os serviços a cargo das 2.100 coletorias federais disseminadas pelo território nacional, e controlar a inspeção dessas repartições arrecadadoras, realizada através de uma rêde de 81 Inspetores de Coletorias, fui chamado a examinar o texto dos Decretos números 49.592 e 49.593, ambos datados de 27 de dezembro de 1960 , e que tratam da regulamentação e classificação das funções gratificadas do Serviço Civil do Poder Executivo, com o fim de verificar as repercussóes do conteúdo dêsses decretos, no tocante às 
diversas chefias dos órgãos compreendidos no setor administrativo fazendário, que dirigem e controlam as coletorias federais.

Para os que se interessarem mais diretamente sôbre a questão, devo dizer que o resultado dêsse despretencioso trabalho por mim realizado consta de um longo comentário que deu origem ao processo SC $n^{\circ}$ 18.430 61, do Ministério da Fazenda, no qual focalizo o tema sob o ponto-de-vista da hierarquia funcional, analogia das funções e impertância, vulto e complexidade das respectivas atribuições, elementos êsses que constituem o fundamento da r'egulamentação e classificação estabelecidas pelos referidos decretos.

Em linhas gerais, resse pronunciamento evidenciei, no que diz respeito às funções gratificadas relacionadas com o Serviço de Coletorias Federais, que a classificação ali adotada não obedeceu ao principio de hierarquia, pois que foram atribuidos a funções hieràrquicamente iguais simbolos diferentes, e a funções subordinadas simbolos iguais ou maiores que os conferidos a outras manifestamente mais elevadas na escala hierárquica, verificando-se, assim, não uma observância, mas antes uma subversão da ordem estabelecida por êsse princípio.

Naquele articulado, insurgi-me com certa reemência (talvez porque falasse por meu intermédio o espirito de classe), contra o fato de haver sido suprimida das tabelas de classificação das funções gratificadas, anexas ao Decreto $n^{2} 49.593$ acima citado, a correlação entre o cargo de exator e tôdas as funções adminictrativas relacionadas com o aparelho arrecadador federal, ou mais precisamente, com tôdas as funções vinculadas ao setor de coletorias federais. E lamentava, com indisfarçável amargura, o não figurarem os cargos de Coletor e Escrivão de Coletoria correlacionados com qualquer das funções constantes daquelas tabelas. numa exclusão absoluta, como se não existisse no quadro do pessoal do Ministério da Fazenda essa espécie de funcionário. Entendia, então, que o fazer coincidir a função do Oficial de Adm:nistração com as chefias de Serviços e Seções compreendidas no setor de coletorias, representava uma distorção, ou mais que isto, uma usurpação, que significava a formação de castas dirigentes, no seio da administração fazendária federal. E citava, como exemplo para argumentação, a função de Delegado Fiscal do T'esouro Nacional nos Estados, cuja analogia de funções, tal como figura na tabela de classificação, corresponde às atribuições de cargo de Oficial de Administração, quando se torna evidente que, dada a natureza das tarefas desempenhadas pela Delegacia Fiscal, ôrgão predominantemente controlador das coletorias federais e orientador da fiscalização, no âmbito de sua jurisdição melhor estariam correlacionadas as funções de seu titular - o Delegado 
Fiscal - com as de qualquer dos integrantes de nivel superior das classes compreendidas no Grupo Ocupacional Fisco.

O tom enfático com que, então, defendia o meu ponto-devista não refletia apenas o interêsse de grupo, ou solidariedade com a minha classe, que eu julgava prejudicada, mas se apoiava também nos dados da moderna ciência da administração, segundo a qual se exige do ocupante dos cargos de chefia um minimo de capacidade técnica, pertinente às tarefas executadas pela emprêsa ou órgão administrado, que, no caso focalizado, se traduzia no conhecimento especifico das atribuições inerentes às coletorias federais.

Todavia, com o passar do tempo, refletindo mais detidamente sôbre o assunto, posso hoje formar a seu respeito um juizo mais sereno e amadurecido, admitindo já agora, sem incorrer em contradição, a vantagem, senão necessidade se destinarem, no corpo da administração pública federal, certas e determinadas classes, em número reduzido, ao desempenho das funções de chefia, mesmo a de órgãos que têm por finalidade a execução de serviços especializados, como os que integram, na administração fazendária, os setores de arrecadação e fiscalização.

Nada impede, por exemplo, que as funções de Auxilar de Assessor de Gabinete, bem assim as de chefia de Direitorias, Departamentos, Divisões, Serviços e Seções do Ministério da Fazenda, inclusive as repartições de escalão mais elevado, tais como a Direção-Geral da Fazenda Nacional, Diretoria das Rendas Internas, Diretoria das Rendas Aduaneiras e Divisão do Impôsto de Renda, para só mencionar os órgãos de cúpula mais estreitamente ligados à arrecadação, nada impede, dizia, que essas chefias sejam ocupadas por Técnicos ou Oficiais de Administração, desde que preencham, é claro, os indispensáveis requisitos referentes à capacidade moral, intelectual e prática do ocupante, inclusive a necessária experiência técnico-administrativa para o exercício dessas altas funções.

Semelhante tirocínio, parece-me que se pode adquirir mediante a ação conjugada de adequada preparação de servidores, julgados com aptidão para o desempenho de cada uma dessas chefias, com o conhecimento prático obtido através do trato constante com os assuntos administrativos da alçada dos órgãos respectivos, - que se poderá alcançar com os méos seguintes:

a) seleção dos servidores integrantes das classes de Técnico de Administração e Oficial de Administração que demonstrem pendores para as funções de chefia dos órgãos que compõem o sistema arrecadador federal;

b) criterinsa escolha das matérias que devem constituir os cursos a serem ministrados ao servidor, de rnaneira gradativa e 
sistemática, como condição para se poder ocupar cada uma das chefias, escalonadas segundo a ordem h:erárquica dos órgãos correspondentes;

c) exigência de um razoável período de permanência do servidor, à guisa de estágio, na chefia de escalão inferior, como condição para ingresso no curso que, uma vez concluído, o credenciará a ocupar a chefia imediatamente superior.

Quanto às matérias a serem transmitidas aos candidatos ao preenchimento de cargos de chefia de órgãos controladores das repartiçc̃es arrecadadoras, tais como Diretoria das Rendas Internas, Diretoria das Rendas Aduaneiras, Delegacias Fiscais, Serviço de Coletorias Federais, etc., além das disciplinas gerais, como sejam, direito administrativo, estatística e outras constantes dos cursos de preparação para as chefias dos demais setores administrativos do Ministério da Fazenda, para aquêles casos deverá ser incluido, obrigatòriamente, não apenas a parte referente à legislação fazendária, contabilidade pública e direito financeiro, mas também o conhecimento prático dos serviços próprios de uma Recebedoria, Coletoria ou Mesa de Rendas Alfandegada, adquirido através de estágio realizado, durante um certo período, nessas estações arrecadadoras.

Desta forma, o critério para a escolha do titular dos órgãos administrativos fazendários, de efeitos tão decisivos para a normalização dêste importante setor da administração federal mormente nos casos de maior relevância, ligados à chefia das repartições de categoria superior - ficaria escoimado dos vicios que hoje o empanam, afastando as influências estranhas ao verdadeiro interêssse público, ao erigir o curriculum vitae funcional como o único meio adequado para a seleção do chefe administrativo decorrenćn daí a necessidade urgente da criação de Escolas de chefia, destinadas à formação e treinamento dêsse tipo de servidor, que terá por missão conduzir, com eficiência, os: negócios públicos, na esfera administrativa.

Voltando ao assunto abordado no início dêste comentário, sôbre a exclusão do cargo de exator da correlação de funções constantes das aludidas tabelas, aceito hoje sem relutância, como afirmei, a orientação adotada pelo citado Decreto $n^{\circ} 49.593$ de 1960, justificando esta mudança de opinião sôbre a questão, na consideração de que, dada a importância com que se apresenta, no quadro das atividades estatais, a função de arrecadar as rendas públicas, e seu indispensável complemento - a fiscalização dos tributos que as constituem - cuja peculiar complexidade exige técnica própria na sua execução (de que, por isto mesmo, sòmente um corpo de agentes especializados dela se pode encarregar satisfatòriamente), êsses agentes - exator e fiscal - uma vez incor- 
porados aos respectivos quadros, depois de habilitados para nêles ingressarem, não devem ser deslocados de suas funções. Isto para que não ocorra sejam perturbados os serviços de que se acham incumbidos, com resultados danosos para o setor em que atuani, $e$, conseqüentemente, para todo o organismo do Estado, que se mantém por via da arrecadação das rendas públicas.

Reformo, igualmente, minha opinião anterior quanto à iniciativa de se restringir aos ocupantes de umas poucas e determinadas classes funcionais, como sejam, Técnico de Administração e Oficial de Administração, a prerrogativa de exercer função de chefia, com exclusão de outras categorias funcionais, pois vejo hoje nesta medida a vantagem de concentrar num limitado e bem selecionado grupo o esfôrço de preparação, desde o ingresso de seus componentes no serviço público, para a difícil missão de dirigir, não havendo nisso o perigo da formação de castas funcionais no seio da administração, alegado por mim no citado pronunciamento, visto que o acesso às classes funcionais destinadas a exercer cargos de direção, é franqueado a todos, sendo que para o caso de funcionários pertencentes a outras carreiras, que aspirem a ocupar cargos de chefia, ou revelem aptidão para tal, haverá o recurso da readaptação, previsto no nosso direito administrativo.

Como está patente, as considerações aqui expedidas não têm outro propósito que o de focalizar o problema da chefia dos órgãos de contrôle, integrantes do sistema arrecadador federal, bem como ressaltar a necessidade urgente da criação de estabelecimentos de ensino, destinados à preparação e treinamento de chefes, que atuarão na administração pública, em geral, e fazendária, em particular.

Alimento a convicção de que, com o aprimoramento sistemático dos conhecimentos técnico-administrativos dos atuais servidores federais que exercem cargos de chefia; com a formação de novos elementos humanos, que com mentalidade mais robusta, virão integrar a equipe dos futuros chefes do serviço público; e com a conseqüente introdução de novos padrões de aferimento de valores, decorrente dessa nova orientação, dentro de um breve espaço de tempo estará a crise de chefia, que constitui um dos mais sérios problemas com que se debate, presentemente, a administração pública, inteiramente debelada.

Está nas mãos dos atuais responsáveis pelos destinos do país, o dispor as coisas neste sentido. Da atual Direção-Geral do D.A.S.P., que tem à sua frente um técnico de notória competência, e da comissão que ora se empenha em promover a reforma do Ministério da Fazenda, muito se pode esperar, neste particular, de cujo esclarecido esfôrço poderá surgir a desejada solução, para a momentosa questão aqui debatida. 